\title{
Cushing's syndrome induced by misuse of topical corticosteroids in a child with psoriasis vulgaris
}

\author{
Githa Rahmayunita $^{1}$, Aman B. Pulungan ${ }^{2}$, Benny E. Wiryadi ${ }^{1}$, Tina Wardhani Wisesa ${ }^{1}$, Titi Lestari Sugito ${ }^{1}$, \\ Siti Aisah Boediardja ${ }^{1}$
}

\begin{abstract}
Abstrak
Pemberian kortikosteroid jangka panjang dapat menyebabkan sindrom Cushing. Namun timbulnya sindrom Cushing akibat penggunaan kortikosteroid topikal jarang ditemukan. Seorang anak laki-laki berusia 71/2 tahun menderita psoriasis vulgaris sejak usia 2 tahun. Ia diobati oleh dokter spesialis kulit dengan racikan asam salisilat 3\%, liquor carbonis detergens 5\%, 10 gram salap mometason furoat 0,1\%, serta 5 gram krim campuran yang terdiri atas gentamisin sulfat 0,1\% dan fluosinolon asetonid 0,025\%. Orang tua pasien melanjutkan terapi ini tanpa seizin dokter. Mereka mengoleskannya ke seluruh tubuh pasien tiga kali sehari selama 31/2 tahun. Pada pemeriksaan didapatkan hipertensi derajat ringan, wajah bulan, buffalo hump, obesitas, strie multipel, dan penekanan aksis hipotalamushipofisis-adrenal. Hasil pemeriksaan bone mineral density dan bone age dalam batas normal. Anak lebih rentan terhadap efek samping sistemik akibat penggunaan obat topikal. Hal ini disebabkan rasio luas permukaan tubuh total terhadap berat badan yang lebih tinggi. Kortikosteroid harus digunakan secara hati-hati, khususnya pada anak. Memberitahu orang tua mengenai efek samping kortikosteroid yang mungkin terjadi sangatlah penting. (Med J Indones 2008; 17: 281-6)
\end{abstract}

\begin{abstract}
Prolonged exogenous corticosteroid administration may cause Cushing's syndrome. However, the development of Cushing's syndrome from topical corticosteroid therapy is rare. A 71/2-year-old boy has suffered from psoriasis vulgaris since the age of two. He was treated by a dermatologist with a mixture of $3 \%$ salicylic acid, $5 \%$ liquor carbonis detergens, 10 grams of $0.1 \%$ mometasone furoate ointment, and 5 grams combination cream consisting of $0.1 \%$ gentamycin sulphate and $0.025 \%$ fluocinolone acetonide. The parents continued the treatment without the doctor's supervision. They applied it to all over the patient's body three times daily for 31/2 years. The patient showed mild hypertension, moon face, buffalo hump, obesity, multiple striae, and suppression of hypothalamus-pituitary-adrenal axis. The bone mineral density and bone age examinations revealed normal results. Children are more prone to develop systemic side effects of topical medication because of their higher ratio of total body surface area to body weight. Corticosteroid must be used with great care, especially in children. It is very important to inform the parents about potential side effects of corticosteroid. (Med J Indones 2008; 17: 281-6)
\end{abstract}

Keywords: Cushing's syndrome - topical corticosteroids, side effects

Psoriasis is a common immune-mediated disorder ${ }^{1}$ characterized by round, erythematous, well-marginated plaques covered by a characteristic grayish or silverywhite scales with predilection on the scalp, elbows, knees, lumbosacral and anogenital regions. ${ }^{1,2}$ Psoriasis

\footnotetext{
1 Department of Dermato-venereology, Faculty of Medicine, University of Indonesia/Dr. Cipto Mangunkusumo Hospital, Jakarta, Indonesia

2 Pediatric Endocrinology Division, Department of Child Health, Faculty of Medicine, University of Indonesia/Dr. Cipto Mangunkusumo Hospital, Jakarta, Indonesia
}

most often begins after puberty, but in $10 \%$ of patients, it begins before the age of ten and $2 \%$ before the age of two. ${ }^{2}$ Between 2001-2005, in the Pediatric Dermatology Division of Dermatovenereology Department, Dr. Cipto Mangunkusumo General Hospital, we have found 40 new cases of psoriasis vulgaris. Twenty seven cases of them were 5-14 years of age. ${ }^{3}$

Many factors should be considered in choosing treatment for psoriasis, ${ }^{4}$ especially in children. ${ }^{2}$ Topical corticosteroid is used for small localized psoriasis lesions. ${ }^{5}$ Prolonged use of topical corticosteroid may cause local and systemic side effects. One of the 
systemic side effects is Cushing's syndrome or the physical manifestation of hypercortisolemia. ${ }^{6}$ Most cases of Cushing's syndrome are iatrogenic and due to prolonged use of oral corticosteroid. ${ }^{7,8}$ The development of Cushing's syndrome from topical corticosteroid therapy is rare. ${ }^{7,9}$ We report a case of Cushing's syndrome which was induced by misuse of topical corticosteroids in a child with psoriasis vulgaris.

\section{CASE REPORT}

A $7 \frac{1}{2}$-year-old boy came to our outpatient clinic on July 20, 2005. He has suffered from psoriasis vulgaris since the age of two, which became wide spread since the age of four. Three and a half years ago, he was treated by a dermatologist with a mixture of $3 \%$ salicilyc acid, 5\% liquor carbonis detergens, 10 grams of $0.1 \%$ mometasone furoate ointment, and 5 grams combination cream consisting $0.1 \%$ gentamycin sulphate and $0.025 \%$ fluocinolone acetonide. There was improvement after using this medication and the parents continued the treatment without the doctor's supervision. They kept buying the prescription every 2 days because the lesions reappeared whenever they discontinued it. The medication had been applied to all over the patient's body three times daily, continuously for almost $3 \frac{1}{2}$ years. There was no other medication, topical nor systemic. Because of drug dependency, the parents stopped the treatment 2 weeks before visiting our outpatient clinic. This patient also had a history of small for gestational age (SGA) or intra-uterine growth restriction (IUGR) because he was born preterm with 2400 grams birth weight.

From physical examination we noted an obese patient with $54 \mathrm{~kg}$ body weight and $132 \mathrm{~cm}$ height (body surface area: $1.35 \mathrm{~m}^{2}$, body mass index: 28.69 or $>95$ percentile). His blood pressure was $120 / 80 \mathrm{mmHg}$ and this was considered as mild hypertension according to The Second Task Force curve. ${ }^{10}$ We also noted moon face (Figure 1) and buffalo hump (Figure 2).

From dermatological findings, there were multiple erythematous plaques, lenticular to plaque in size, with rough transparent scales on the trunk, both arms, and legs (Figure $3 \mathrm{~A}, \mathrm{~B}$ ). Psoriasis area severity index (PASI) score was 6.2. On the upper arms, buttock, abdominal area, and lower extremities, multiple hyperpigmented striae were noted (Figure 4 A,B,C).

From laboratory examination, the complete blood counts were within normal limits. The ureum level was $16 \mathrm{mg} \%$ (normal value: $15-38 \mathrm{mg} \%$ ), the creatinine level was $0.55 \mathrm{mg} \%$ (normal value: $0.5-1.5 \mathrm{mg} \%$ ), the ALT level was $28 \mathrm{mU} / \mathrm{ml}$ (normal value: $<47$ $\mathrm{mU} / \mathrm{ml}$ ), and the AST level was $24 \mathrm{mU} / \mathrm{ml}$ (normal value: $<39 \mathrm{mU} / \mathrm{ml}$ ). The plasma sodium level was 144 $\mathrm{mEq} / \mathrm{L}$ (normal value: $135-147 \mathrm{mEq} / \mathrm{L}$ ) and the plasma potassium level was $5.2 \mathrm{mEq} / \mathrm{L}$ (normal value: $3.5-5.5$ $\mathrm{mEq} / \mathrm{L}$ ). The fasting blood sugar level was $75 \mathrm{mg} / \mathrm{dl}$ (normal value: $70-110 \mathrm{mg} / \mathrm{dL}$ ) and postprandial blood sugar level was $80 \mathrm{mmHg}$ (normal value: $<140 \mathrm{mg}$ / $\mathrm{dL}$ ). The bone mineral density was also within normal limit. The bone age was equal to a 7 -year-old boy with normal bone remodeling and the conclusion was that the patient was normal. Morning plasma cortisol level was $4.54 \mu \mathrm{g} / \mathrm{mL}$ (normal value: $5-25 \mu \mathrm{g} / \mathrm{mL}$ ), while evening plasma cortisol level was $5.54 \mu \mathrm{g} / \mathrm{mL}$ (normal value: $2.5-12.5 \mu \mathrm{g} / \mathrm{mL}$ ).

Hewastreated withnarrowband(NB)UVB phototherapy three times weekly, starting from 30 seconds duration of exposure. The duration of phototherapy was increased gradually. The patient developed erythroderma after four exposures to NB UVB phototherapy and therefore the treatment was stopped and switched to acitretin 25 $\mathrm{mg}$ three times a week. After taking this medication for 5 weeks, the lesions were almost completely cleared and the treatment was stopped.

Eight months after stopping the acitretin, the psoriasis lesions remained under remission. Ten months after stopping the topical corticosteroids, the moon face was subsided and the blood pressure was already normal $(110 / 70 \mathrm{mmHg}$ ). His body weight was $48 \mathrm{~kg}$ (Figure 5 A,B) and morning plasma cortisol level was $7.2 \mu \mathrm{g} / \mathrm{mL}$ (normal value: $5-25 \mu \mathrm{g} / \mathrm{mL}$ ). 


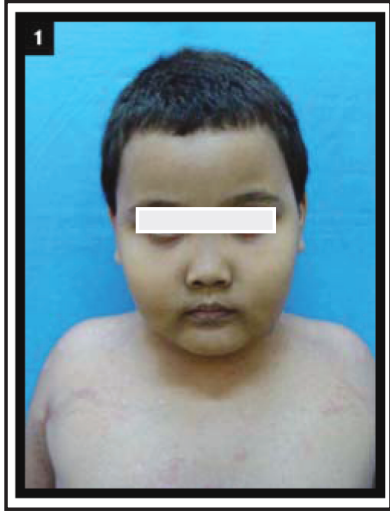

Figure 1. Moon face

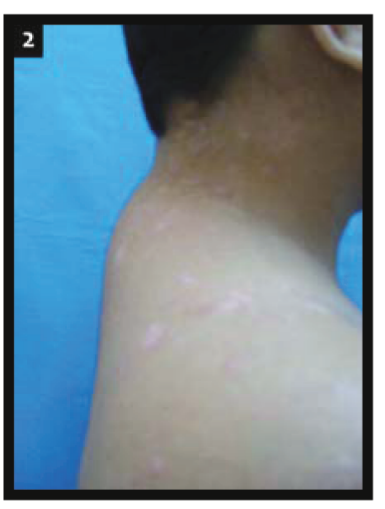

Figure 2. Buffalo hump

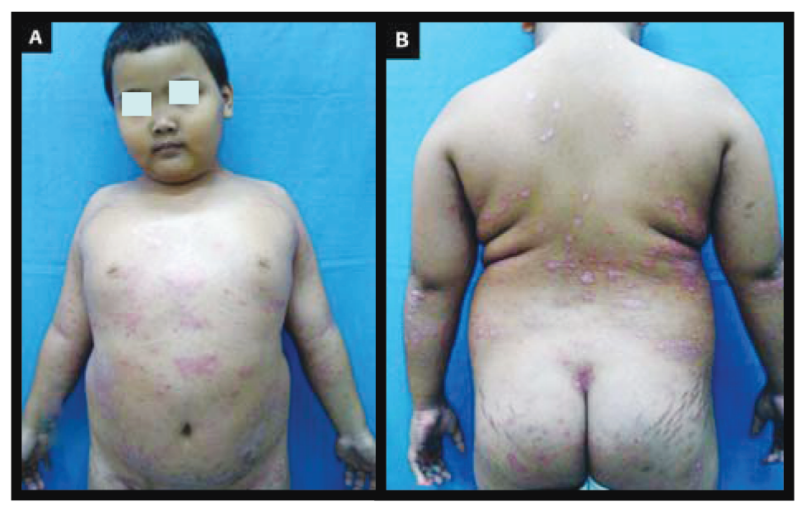

Figure 3 A,B . Erythematous plaques with scales on the trunk and arms

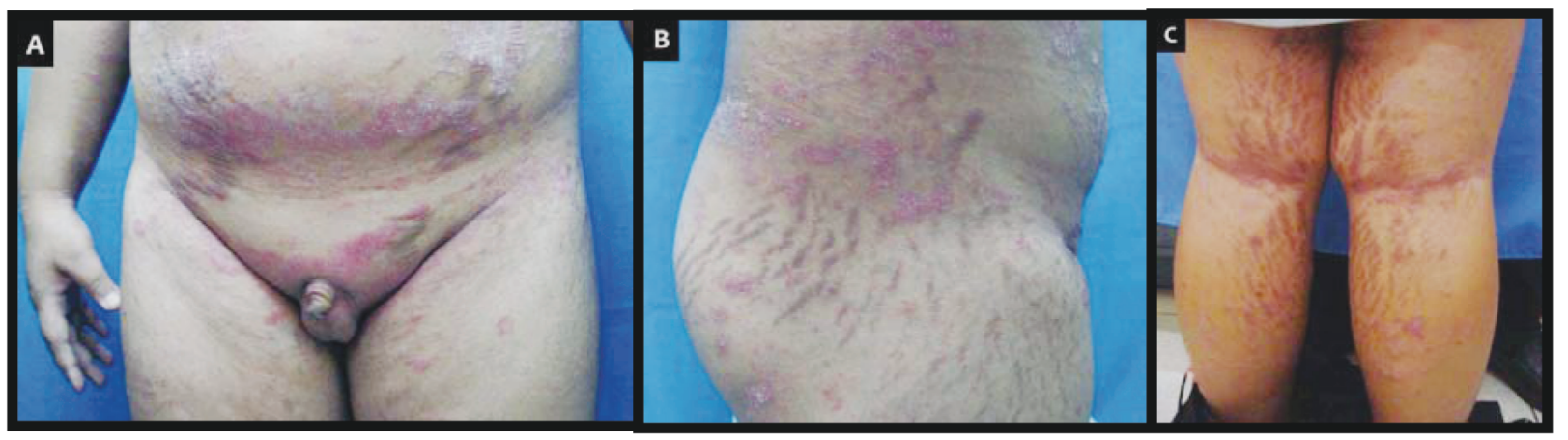

Figure 4 A,B,C. Multiple striae on abdominal area, buttock, and lower extremities
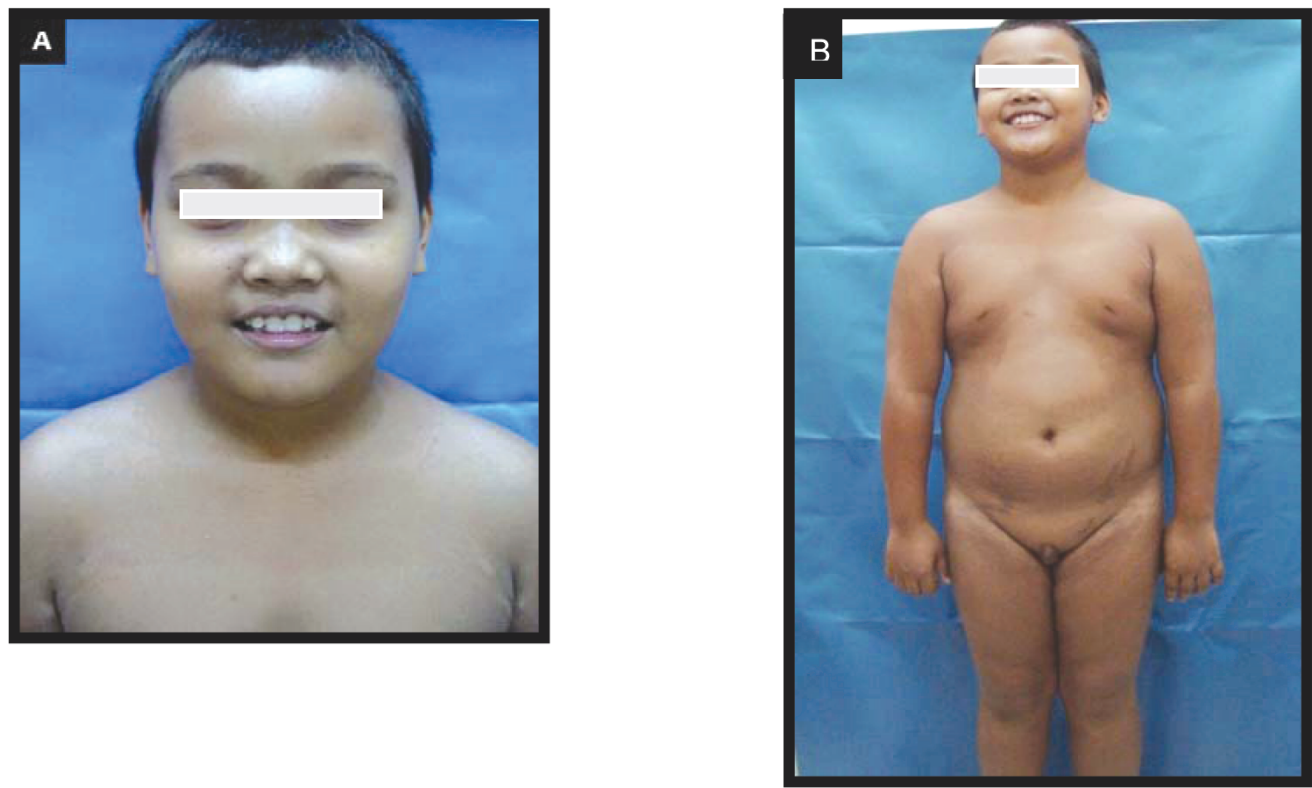

Figure 5 A,B. Ten months after stopping topical corticosteroids the moon face subsided and the body weight decreased 


\section{DISCUSSION}

Many factors should be considered in choosing treatment for psoriasis, such as the age of the patient, the extent and activity of the disease, site to be treated, possible side effects, and compliance. ${ }^{4}$ Treatments suggested for psoriasis in children are listed in table 1.

Topical corticosteroid is used for small and localized psoriasis lesions. ${ }^{5}$ Prolonged use of this medication may cause local and systemic side effects. ${ }^{6}$ The development of side effects is influenced by the amount applied, frequency of application, concentration and potency of the corticosteroid, percentage of body surface covered, occlusion, long-term use, and age of patients. One of the systemic side effects is Cushing's syndrome. ${ }^{6,11}$ Cushing's syndrome is a disorder caused by long-term glucocorticoid excess, which may be due to a variety of different etiologies. ${ }^{1}$ Most cases of Cushing's syndrome are iatrogenic and due to prolonged use of oral corticosteroid. ${ }^{7,8}$ Very rarely, topical corticosteroid therapy can lead to the development of Cushing's syndrome. ${ }^{7,9}$
This patient has already suffered from psoriasis for $5 \frac{1}{2}$ years. The parents continuously applied a combination of the class 2 (potent) and the class 5 (midstrength) corticosteroids on a large body surface area for a long period. Children are more prone to develop systemic side effects of topically applied medication because of their higher ratio of total body surface area to body weight (2.5 to 3 fold of adults). ${ }^{11}$ According to growth charts of Centers for Disease Control and Prevention (CDC), his body weight was higher than 95 percentile and height was at 90 percentile, ${ }^{12}$ thus he had a large body surface area for his age $\left(1.35 \mathrm{~m}^{2}\right)$. Therefore the amount of applied medication that was absorbed became much more systemically and the risk of systemic side effects was also increased.

Cushing's syndrome in this case was based on the presence of mild hypertension, moon face, buffalo hump, obesity, multiple striae, and suppression of hypothalamus-pituitary-adrenal (HPA) axis (decreased morning plasma cortisol level). His blood pressure was $120 / 80 \mathrm{mmHg}$ and this was considered as mild hypertension, because according to The Second Task Force curve, the normal blood pressure for an 8-yearold boy is $114 / 73 \mathrm{mmHg} .{ }^{10}$

Table 1.Treatments suggested for psoriasis in children (cited from reference number 2)

\section{SEVERITY}

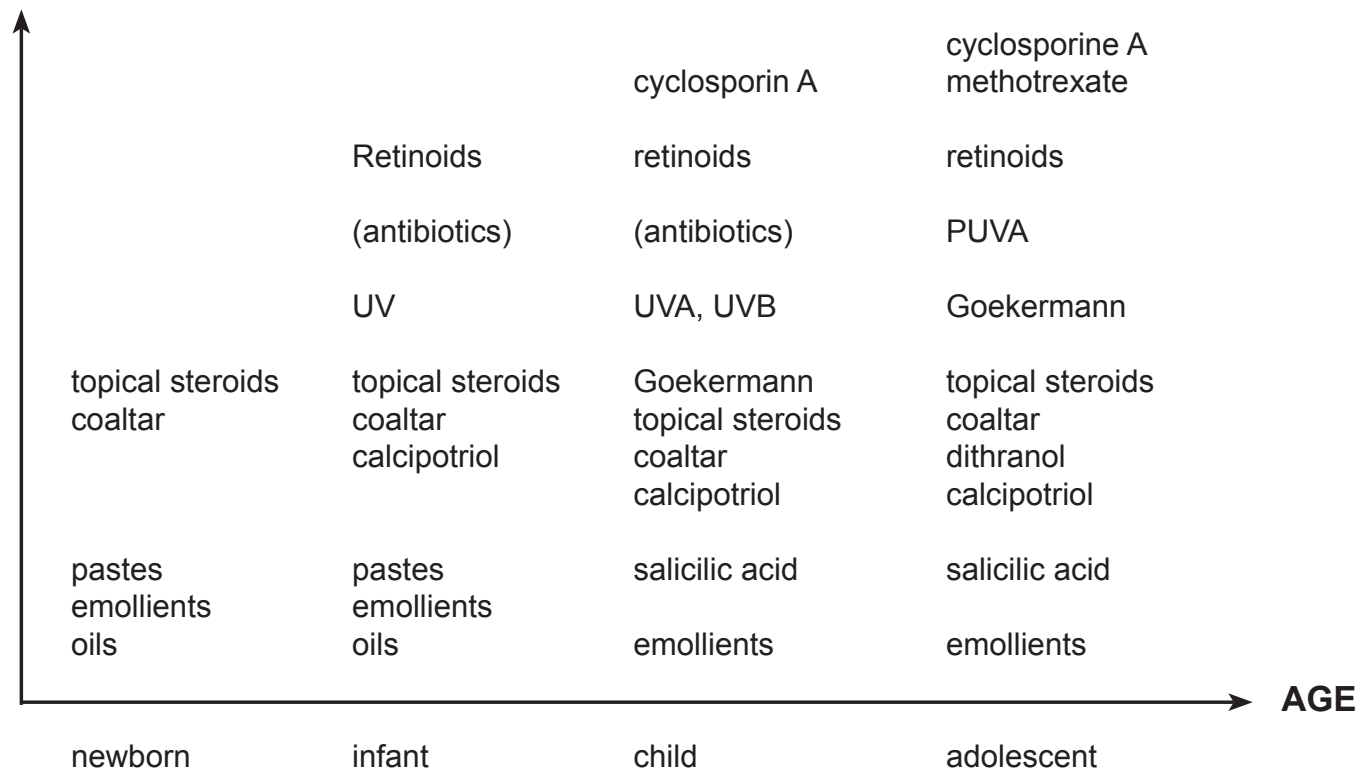


The morning plasma cortisol level in this case was below the normal level. In normal condition, plasma $\mathrm{ACTH}$ and cortisol reach the highest levels in the morning and the lowest levels in the evening. ${ }^{13}$ The exogenous corticosteroid inhibit hypothalamic corticotropin releasing hormone and pituitary ACTH secretion, therefore the ACTH and plasma cortisol levels are low. ${ }^{14}$ Factors promoting the penetration of the topical corticosteroid increase the possibility for HPA axis suppression. In this case, the ointment itself as well as 3\% salicylic acid could enhance corticosteroids penetration. Absorption of super potent and potent topical corticosteroids is able to produce rapid suppression of plasma cortisol levels even through normal healthy skin. ${ }^{15}$

Another main concern of corticosteroid side effects in children is growth retardation, but it was not found in this patient as the bone age and the bone mineral density examinations revealed normal results. The topical medication was stopped 2 weeks before his visit to our clinic. A sudden discontinuation of corticosteroid may have caused an adrenal crisis, ${ }^{7}$ but the signs and symptoms of adrenal crisis were not found in this case.

Once the diagnosis of Cushing's syndrome is established, the exogenous corticosteroid should be discontinued. ${ }^{16}$ In a patient with confirmed HPA axis suppression, a program of tapering oral corticosteroid and reduction of potency and amount of topical corticosteroid is needed. ${ }^{6,16}$ The length and rate of the taper course depend on the length of the topical corticosteroid use, the dosage or the amount used, and the degree of adrenal suppression. ${ }^{6}$ Morning cortisol values of $10 \mu \mathrm{g} / \mathrm{dL}$ or more indicate that the dose of corticosteroid can be reduced safely. ${ }^{17}$

Initially, the patient was treated with NB UVB phototherapy. Although the PASI score was 6.2, this modality was chosen because the distribution of the psoriasis lesions was wide spread. Normally, the frequency of the treatment is three times weekly until remission is achieved, and the frequency is reduced during maintenance dose. ${ }^{5}$ This patient developed erythroderma after four exposures of NB UVB phototherapy and therefore the treatment was stopped and switched to acitretin. Psoriatic erythroderma may be the response to nontolerated topical treatment such as UVB. ${ }^{18}$ The recomended acitretin dosage for psoriasis vulgaris is $0,5-1 \mathrm{mg} / \mathrm{kg} /$ day. ${ }^{1}$ This medication can also be given for psoriatic erythroderma with reduced dosage. ${ }^{19}$ After taking this medication for 5 weeks, the lesions were almost completely cleared and the treatment was stopped.

The prognosis of Cushing's syndrome in this patient is good. The striae are permanent, but other signs and symptoms are reversible. ${ }^{11}$ As seen at follow up, 10 months after stopping the corticosteroids the moon face subsided, the obesity decreased, the blood pressure and the morning plasma cortisol level returned to normal. In this patient, we found obesity, hypertension, Cushing's syndrome, and a history of SGA or IUGR, therefore he is more prone to develop metabolic syndrome. The criteria of the National Cholesterol Education Program (Adult Treatment Panel/ATP III) for diagnosing the metabolic syndrom in children and adolescents are obesity (waist circumference: $>90$ percentile), increased triglycerides level ( $>110 \mathrm{mg} / \mathrm{dL})$, low HDL cholesterol level $(<40 \mathrm{mg} / \mathrm{dL})$, elevated blood pressure $(>90$ percentile), and elevated fasting glucose level $(>110$ $\mathrm{mg} / \mathrm{dL}$ ). The presence of any three of these five criteria are sufficient to make the diagnosis. ${ }^{20}$

Eight months after stopping the acitretin, the psoriasis lesions were still under remission. But the occurrence of psoriasis in childhood has poorer prognosis because it tends to be more extensive and troublesome. ${ }^{4}$

The British National Formulary (cited from reference number 11) emphasizes that children are particulary susceptible to side effects. This organization recommends that in general, topical corticosteroid should be avoided in children or, if necessary, used with great care and for short periods. Limiting the use of corticosteroid, prescribing less potent agents, especially during childhood, and warning the parents about potential side effects are very important. ${ }^{9}$

\section{REFERENCES}

1. Paller AS, Mancini AJ. Hurwitz Clinical Pediatric Dermatology: A textbook of skin disorders of children and adolescence. $3^{\text {rd }}$ edition. Chicago: Elsevier Saunders; 2006.

2. Gelmetti C, Caputo R. Psoriasis in childhood. In: Dubertret L, editor. Psoriasis. Italy: Ised; 1994. p.248-58.

3. Morbidity report of Pediatric Dermatologic Division, Department of Dermatovenereology, Faculty of Medicine University of Indonesia, Dr. Cipto Mangunkusumo General Hospital, Jakarta, Indonesia. 2001-2005.

4. Higgins EM, duVivier A. Glucocorticoid. In: Dubertret L, editor. Psoriasis. Italy: Ised; 1994. p.102-10.

5. Wiryadi BE. Penatalaksanaan psoriasis. Simposium cantik bersama psoriasis; 2004 March 6; Jakarta, Indonesia. 
6. Gilbertson EO, Spellman MC, Piacquadio DJ, Mulford MI. Super potent topical corticosteroid use associated with adrenal suppression: Clinical considerations. J Am Acad Dermatol 1998; 38: 318-21.

7. Alnabelsi $\mathrm{K}$, Jardine $\mathrm{M}$, Wexler J, Imperato-McGinley. Corticosteroids and the endocrine system. In: Lin AN, Paget SA, editors. Principles of corticosteroid therapy. New York: Arnold; 2002. p.100-23.

8. Price NJ, Bertagna X, Grossman AB, Nieman LK. Cushing's syndrome. The Lancet 2006; 367: 1605-17.

9. Siklar Z, Bostanci I, Atli O, Dallar Y. An infantile Cushing syndrome due to misuse of topical steroid. Pediatr Dermatol 2004; 21: 561-3.

10. Bahrun D. Hipertensi sistemik. In: Alatas H, Tambunan T, Trihono PP, Pardede SO, editors. Buku ajar nefrologi anak. Jakarta: Gaya Baru; 2002. p.242-9.

11. Hengge UR, Ruzicka T, Schwartz RA, Cork MJ. Adverse effects of topical glucocorticosteroids. J Am Acad Dermatol 2006; 54: 1-15.

12. Vital and Health Statistics of the Centers for Disease Control and Prevention/National Center for Health Statistics. CDC Growth Charts: United States. 2000 Dec (cited 2006 Augt 18). Available from: URL: http://www.cdc.gov/nchs.
13. Schmidt TJ. Physiological functions of corticosteroids. In: Lin AN, Paget SA, editors. Principles of corticosteroid therapy. New York: Arnold; 2002. p.19-40.

14. Miyachi Y. Pathophysiology and diagnosis of Cushing's syndrome. Biomed \& Pharmacother 2000; 54: S113-7.

15. Tennstedt D, Lachapelle JM. Systemic side effects of topical corticosteroids: How to recognize them in time, how to limit or avoid them. J Eur Acad Dermatol Venereol 1995; 5: S57.

16. Kimmerle R, Rolla AR. Iatrogenic Cushing's syndrome due to dexamethasone nasal drops. The Am J Med 1985; 79: 535-7.

17. Miller WL. The adrenal cortex. In: Sperling MA, editor. Pediatric endocrinology. 2nd edition. Philadelphia: Saunders; 2002. p.385-428.

18. Gudjonsson JE, Elder JT. Psoriasis. In: Wolff K, Goldsmith LA, Katz SI, Gilchrest BA, Paller AS, Leffell DJ, editors. Fitzpatrick's dermatology in general medicine. $7^{\text {th }}$ edition. New York: McGraw-Hill; 2008. p.169-93.

19. Rosenbach T, Czarnetzki BM. Retinoids. In: Dubertret L, editor. Psoriasis. Italy: Ised; 1994. p.152-60.

20. Jones K. The dilemma of the metabolic syndrome in children and adolescents: disease or distraction?. Pediatric Diabetes 2006; 7: 311-21. 